ІНВЕСТУВАННЯ ВИНОРОБНОЇ ГАЛУЗІ УКРАЇНИ: СТАН ТА ПЕРСПЕКТИВИ

\title{
iNVESTMENT IN THE WINE INDUSTRY OF UKRAINE: STATE AND PROSPECTS
}

Удк 330.322.16

DOI: https://doi.org/10.32843/infrastruct50-10

\section{Соколюк К.Ю}

к.е.н., старший викладач кафедри маркетингу, підприємництва і торгівлі

Одеська національна академія

харчових технологій

Мільчева В.В.

викладач-стажист кафедри

маркетингу, підприємництва і торгівлі

Одеська національна академія

харчових технологій

Бондарчук Д.О.

студентка

Одеська національна академія

харчових технологій

\section{Sokoliuk Kateryna}

Odessa National Academy

of Food Tehnologies

Milcheva Viktoriia

Odessa National Academy

of Food Tehnologies

Bondarchuk Dariia

Odessa National Academy

of Food Tehnologies у статті розглянуто дослідження використання інвестицій, їх розподіл між галузями. Розкрито сутність інвестиційної привабливості галузі та чинники, що впливають на неї. Розглянуто агропромисловий комплекс за2019 р. та виробництва, які займають найбільші частки. Встановлено за допомогою даних імпорту, що виноробна галузь потребує довготривалих інвестицій, оскільки потрібно збільшувати виробництво, але це займає близько 5 років. Споживання вина в Україні поступається європейським країнам, але галузь має значні перспективи розвитку. Усі перелічені у статті фрактори, такі як зручне географрічне розташування та сприятливі кліматичні умови, доступність сировини та одночасне недостатнє державне стимулювання і фрінансування, зумовлюють необхідність покращення інвестиційної привабливості з метою залучення інвестицій до виноробної галузі для покращення фрінансового стану виноробних підприємств і подальшого виходу виробництва вина на новий рівень.

Ключові слова: інвестиції, інвестиційна привабливість галузі, вино, виробництво.

В статье рассмотрены исследования использования инвестиций, их распределе- ние между отраслями. Раскрыта сущность инвестиционной привлекательности отрасли и фракторы, влияющие на нее. Рассмотрен агропромышленный комплекс за 2019 г. и производства, которые занимают нашбольшие доли. Установлено с помощью данных импорта, что винодельческая отрасль нуждается в долгосрочных инвестициях, поскольку нужно увеличивать производство, но это занимает около 5 лет. Потребление вина в Украине уступает европейским странам, но отрасль имеет значительный потенциал для дальнейшего развития. Все перечисленные в статье фракторы, такие как удобное географическое расположение и благоприятные климатические условия, доступность сырья и одновременно недостаточное государственное стимулирование и финансирование, обусловливают необходимость улучшения инвестиционной привлекательности с целью привлечения инвестиций в винодельческую отрасль для улучшения финансового состояния винодельческих предприятий и дальнейшего выхода производства вина на новый уровень.

Ключевые слова: инвестиции, инвестиционная привлекательность отрасли, вино, производство.

This article considers the use of direct and portfolio investments of national and foreign origin, their distribution between sectors of the economy. The essence of investment attractiveness of the agro-industrial complex and the wine industry in particular, and the factors influencing its formation are revealed. The state of the agro-industrial complex of Ukraine in 2019 is analyzed by industries that occupy the largest shares. It is determined that in the long run, the wine industry is one of the most attractive for investment. Currently, the products of the wine industry of Ukraine are popular abroad. However, given the global trends in this industry, it is necessary to constantly improve technology, and all this requires investment and the appropriate level of knowledge. Investments in the wine industry are quite promising and, at the same time, are long-term. During the writing of the article, it was determined that the optimal payback period for investments in the wine industry is 3-4 years. The priority of the development of this industry is also that according to the research conducted in the article, there is a spatial reorientation of grape growing and wine production. Namely, if earlier the main production was concentrated in the South (Mykolayiv, Kherson regions), then in recent years viticulture is developing in Lviv region and Central Ukraine. In addition, small wineries are developing, which is a positive phenomenon. But the support of the state is already needed here. It is established, based on the study of data on imports in the dynamics, that the wine industry currently needs long-term investment, as it is necessary to increase production, and it takes about 5 years. The study found that foreign investors are currently somewhat wary of long-term investments. According to research, wine consumption in Ukraine is currently inferior to most European countries. However, a set of factors that are studied in the article, contribute to the development of this industry in the future, provided long-term investment. Taking into account all the factors listed in the article, namely: convenient geographical location and favorable climatic conditions, availability of raw materials and, at the same time, insufficient government incentives and funding necessitate improved investment attractiveness in order to attract investment to the wine industry. wine to a new level.

Key words: investments, investment attractiveness of the industry, wine, production.

Постановка проблеми. Останнім часом показники виробництва винограду та виноградної продукції в Україні знижуються, що несе за собою збитки підприємців виноробної галузі. Головним завданням для них стає пошук інвесторів та фрормування таких конкурентних переваг, які стимулюватимуть залучення інвестиційних ресурсів саме в цю галузь. Виноробство $€$ однією з провідних та перспективних у країні галузей, що має великий потенціал. Розвиток виноробної галузі сприятиме покращенню виробничого, техніко-технологічного, соціального напрямів.

Аналіз останніх досліджень та публікацій. Цю проблему вивчали такі вчені, як О.С. Малащук, А.М. Авідзба, В.В. Власов, М.М. Петричко, І.Л. Федуна, В.П. Ситник, Р.А. Фатхутдінов. Незважаючи на значний внесок вітчизняних та іноземних науковців у вивчення цього питання, дослідження інвестиційної привабливості та можливості покращення показників ефрективності розвитку виноробної галузі України, а також виявлення аспектів та чинників для залучення іноземних інвесторів $€$ одним із актуальних завдань перед науковцями в сучасних умовах.

Постановка завдання. Метою дослідження $€$ аналіз інвестиційної привабливості аграрно-промислового комплексу та виноробної галузі зокрема, стану та перспектив залучення внутрішніх та зовнішніх інвестицій для подальшого збільшення виробництва винограду і виноградного вина.

Виклад основного матеріалу. Залучення інвестицій у розвиток економіки України - доволі 
складний та багатогранний процес. На нього впливає ціла низка чинників, що у сумі фрормують інвестиційну привабливість країни, галузі та підприємства зокрема (рис. 1). Усі ці фрактори фрормують макро- і мікросередовище та інвестиційний клімат.

Ключовою під час визначення пріоритетності вкладень іноземних інвестицій все ж таки залишається інвестиційна привабливість країни, фрормування якої залежить від цілої системи чинників, що тісно взаємопов'язані між собою (рис. 2).

Згідно з останніми дослідженнями, Україна покращила позиції у рейтингу Doing Business-2020 і посідає нині 64 місце серед 190 країн. Рейтинг включає оцінку ведення підприємницької діяльності за десятьма показниками [1]. Однією 3 позицій є оцінка інвестиційної привабливості, яка допомагає зрозуміти, чи доцільно буде вкладати інвестору власні кошти в підприємство та у певній країні, враховуючи різноманітні фрактори.
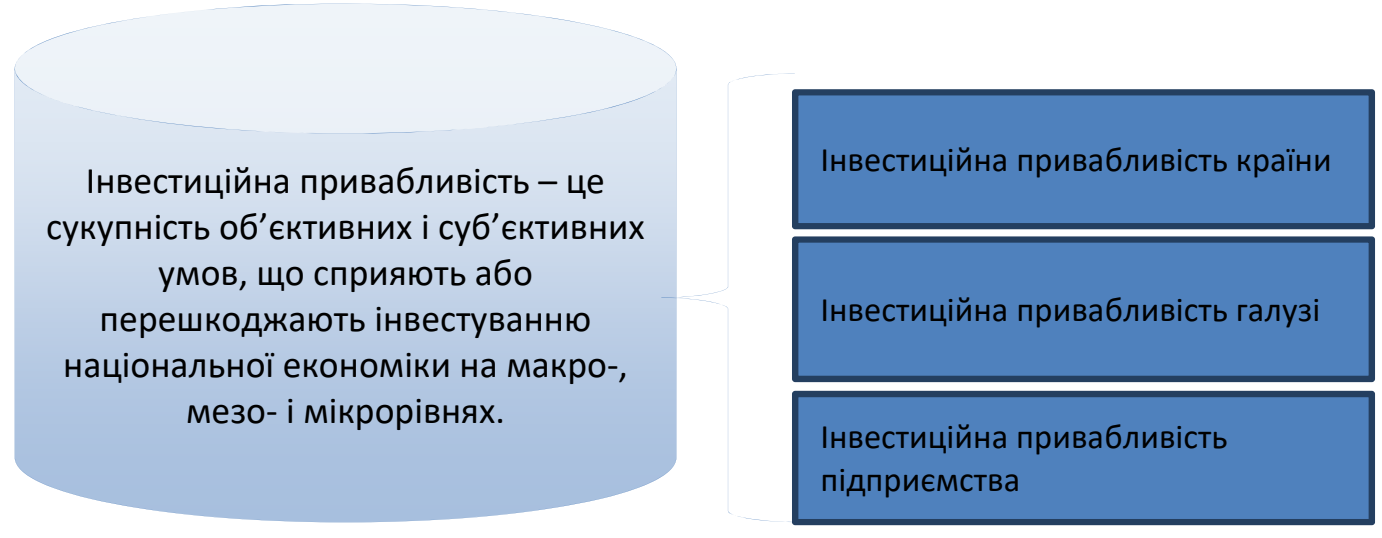

Інвестиційний клімат - це комплекс політичних, соціальних, інноваційних, інфраструктурних елементів, що існують на певній території.

Рис. 1. Формування інвестиційної привабливості - рівні

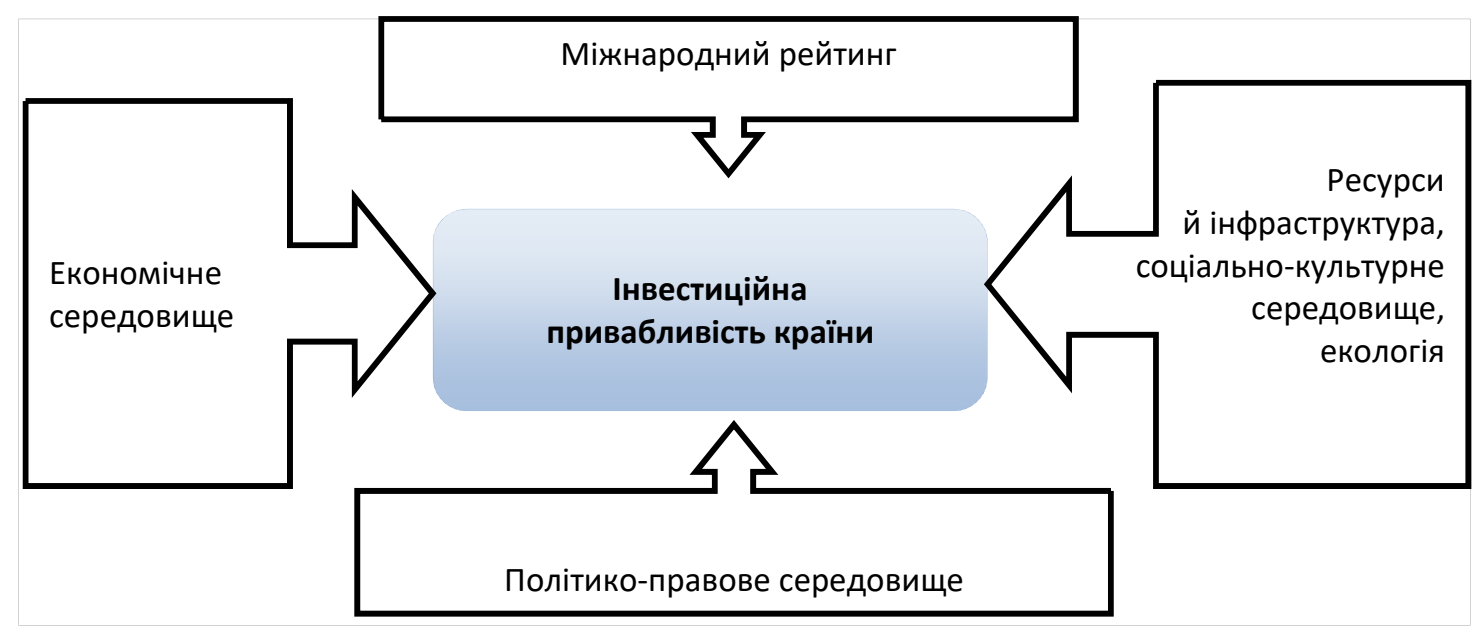

Рис. 2. Чинники впливу на інвестиційну привабливість країни 
резервного капіталу, конкурентоспроможність, стратегії розвитку та просування, підходи до управління та тривалість інвестиційної програми.

Незважаючи на те, що останніми роками спостерігається здебільшого погіршення цих фракторів, все-таки слід розглядати Україну як перспективну державу для залучення іноземних інвестицій [4].

У 2019 році сума загальних інвестицій, вкладених в економіку України, становила 2531,1 млн дол. Найбільша частка припадає традиційно на фрінансову та страхову діяльність - 37\%. На другому місці за часткою - промисловість - 25\% (рис. 3).

На сільське, лісове та рибне господарство припадає лише 3\%, що є вкрай низьким показником. Така структура є доволі несприятливою, оскільки країна неабияк славиться аграрно-промисловим комплексом та харчовою промисловістю.

Проте, незважаючи на досить низьку інвестиційну активність як серед іноземних, так і серед вітчизняних інвесторів, однією 3 найбільш привабливих нині галузей аграрно-промислового комплексу держави є виноградарство та виноробство. Для них є відповідні природні умови та матеріально-технічна база.

Аналізуючи основні показники розвитку цієї галузі, а саме площі виноградників та валові збори винограду, варто відзначити тенденції, що притаманні цій галузі. Площа виноградників за останні роки суттєво не змінилася та становить у середньому 43-43,5 тис. га (у 2014 році площа була майже вдвічі більшою за рахунок АРК). Проте, незважаючи на певне скорочення площ, останніми роками спостерігається нарощування валових зборів, що пояснюється зростанням врожайності винограду (на це впливають як сприятливі кліматичні умови, так і використання інноваційних методів вирощування і нових, більш продуктивних сортів винограду).

Сприяє розвитку виноробної галузі й подальше завоювання міжнародних ринків. Зокрема, у 2018 році експорт українських виноградних вин перевищив імпорт та становив 4469,3 тис дол (імпорт становив 3378 тис. дал) за загальної місткості ринку 5676,7 тис. дал.

Незважаючи на це, виробництво виноградних вин в останні роки зменшилося, а також ринок почав невпинно заповнюватись імпортними товарами й інколи товаром для сегменту з низьким доходом.

32019 р. імпорт вина збільшився на 11,4 млн дол., або на 51\%, та становив 146,7 млн дол., а головними імпортерами є Італія, Франція, Німеччина, про що свідчать дані Державної митної служби (рис. 4).

Однак, враховуючи наповненість ринку імпортними товарами, експорт винної продукції у грошовому вираженні становив 11,9 млн дол., що в 11 разів менше, ніж імпорт.

Експерти зазначають, що виноробство потребує великих інвестицій, оскільки досягнення результату розтягується на роки, враховуючи те, що створення виноградників займає близько 5 років. Це зумовлено насамперед тим, що плодоносити виноградники починають не відразу,

\section{Структура іноземних інвестицій в Україні у 2019 р.}



Промисловість

Оптова та роздрібна торгівля

Фінансова та страхова діяльність

Операції з нерухомості

- Наукова, технічна діяльність

- Діяльність у сфері адміністративного та допоміжного обслуговування

- Будівництво

Транспорт

- Сільське, лісове та рибне господарство

Рис. 3. Структура іноземних інвестицій за галузями в Україні за 2019 р. [4] 


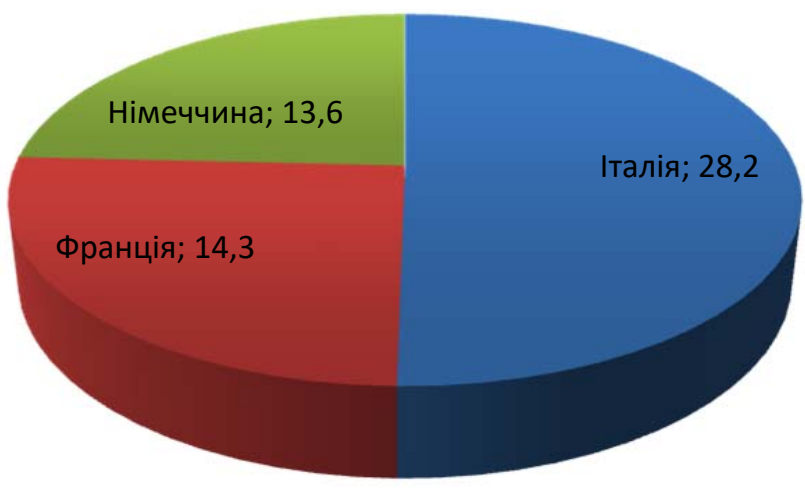

І Італія Франція Німеччина

Рис. 4. Головні імпортери вина за 2019 р. [4]

а через 2-3 роки (в промислових масштабах через 4 роки). Міністерство намагається створити оптимальні умови для виробництва, але власники виноградників витрачають кошти для того, щоб реалізувати продукцію, хоча скасовано ліцензію на право реалізації винопродукції із власних виноматеріалів.

Великим недоліком виноробної промисловості в країні $€$ тіньовий бізнес та можливість власноруч виробляти вино жителям Одеської, Миколаївської, Херсонської областей. Цей фрактор в прямому сенсі блокує отримання точних даних споживання та реалізації продукції.

Попри це, виробництво виноградної продукції та споживання зростає та становить у 2019 році 9117,1 тис. дол., або 6-7 л сухого вина на людину.

Незважаючи на те, що відповідно до структури споживання виноградних вин в Україні перевагу споживачі віддають вітчизняним, вітчизняна продукція й досі програє іноземним винам. У 2018 році структура споживання виноградного вина в Україні була такою: 40,5\% вітчизняного та 59,5\% імпортного, а в 2017-му - 37,2\% та 62,8\% відповідно [5].

Привабливість виноробної галузі для інвестора зумовлена особливими умовами сировинного забезпечення, значенням продукції для внутрішнього ринку, експортними можливостями галузі.

Особливої уваги інвесторів заслуговує рівень державного регулювання галузі, яке стосується насамперед ліцензування, оподаткування та підтримки експорту. Нині ставки акцизного збору на вина становлять 11,65 грн. за 1 літр [6].

3 цього слідує, що основна підтримка спрямована на стимулювання виробництва переважно слабоалкогольних напоїв, до яких також належить і ординарне сухе вино.

За сучасних умов найголовнішим завданням державного регулювання виноробної галузі $€$ сприяння покращенню фрінансового стану вітчизняних виноробних підприємств, оскільки кращим показником інвестиційної привабливості для іноземного інвестора виступають активні внутрішні інвестиції [7].

Варто зазначити, що виноробство - це перспективна галузь із великими можливостями та нерозкритим потенціалом. Враховуючи історичні традиції, особливості технологій виробництва та географрічне положення, можна досягти бажаних прибутків.

Покращення виноробної промисловості та підвищення показників виробництва й експорту виведе країну на шлях зміцнення економіки та сприятиме покращенню відносин із сусідніми країнами шляхом експорту. Галузь може стати провідною у сільськогосподарському комплексі та забезпечувати нові можливості.

Для цього $є$ надважливим залучення довгострокових інвестицій та підтримки вітчизняних виробників. Інвестиції сприяють не тільки розвитку виробництва, але й збільшенню експорту та інтеграції у світову економіку. Порівняно з 2018 роком сума зросла на 11\% у 2019 році, а лідерами інвестування є Нідерланди [8].

Також не обійтися від допомоги з боку влади та надій на впровадження законів, які даватимуть змогу отримувати достатній прибуток та безперешкодно реалізовувати цей вид товару.

Висновки. Таким чином, висвітлені у статті дослідження свідчать про те, що агропромисловий комплекс країни потребує довгострокових інвестицій, як внутрішніх, так і зовнішніх. Особливої уваги заслуговує виноробна галузь України. Поряд із заходами, що сприятимуть підвищенню інвестиційної привабливості виноробної галузі, необхідно підвищувати культуру споживання вина та стимулювати збут вітчизняного виробництва.

Всі перелічені фрактори, такі як зручне географрічне розташування та сприятливі кліматичні умови, доступність сировини та одночасне недостатнє державне стимулювання і фрінансування, зумовлюють необхідність покращення інвестиційної привабливості 3 метою залучення інвестицій до виноробної галузі для покращення фрінансового стану виноробних підприємств і подальшого виходу виробництва вина на новий рівень.

Основними напрямами освоєння інвестицій має бути не лише виробництво якісного винного продукту, але й розвиток ефективної логістики, маркетингу збуту та фрормування позитивного іміджу українського виноградного вина. Нині в Україні $€$ доволі багато відомих виробників якісних вин (виноробне господарство князя М.П. Трубецького, «Курінь», «Шато Чизай», V. Petrov, «Бейкуш», «Колоніст», «Вина Гулієвих», Don Alejandro Winery, Cotnar, «Маркіз де Лакарен» тощо), проте, на жаль, не всі про них знають. Подальшій їх популяризації, окрім уже зазначених інструментів, може сприяти винний туризм - один із перспективних напрямів, що стрімко розвивається. 
Нині є гостра потреба в інвестиціях у саджанці та високопродуктивне обладнання. Проте великі терміни окупності інвестицій поряд із бюрократичними процедурами ліцензування виробництва не сприяють розвитку виноробних регіонів.

\section{БІБЛІОГРАФІЧНИЙ СПИСОК:}

1. Рейтинг Doing Business. URL: https://www. ukrinform.ua/rubric-economy/2805261-rejting-doingbusiness.html (дата звернення: 15.11.2020).

2. Рилєєв С.В., Романчук А.Л. Інвестиційна привабливість: види та підходи до її оцінки: монографрія. Чернівці : Чернівецький торговельно-економічний інститут КНТЕУ, 2013, с. 166.

3. Петричко М.М. Методичні підходи до оцінки ефрективності фрункціонування системи інвестиційного забезпечення інноваційних процесів у виноградарсько-виноробній галузі України: монографрія. Херсон: Науковий вісник Херсонського державного університету, 2014, с. 51.

4. Державна служба статистики України. URL: http://www.ukrstat.gov.ua (дата звернення: 15.11.2020).

5. Кравчук А.О. Проблеми та пріоритетні напрямки розвитку виноградарсько-виноробній галузі України: монограсрія. Економіка та підприємництво, 2019, с. 41.

6. Державна фріксальна служба України. URL: http://sfs.gov.ua (дата звернення: 15.11.2020).

7. Постанова Кабінету Міністрів України від 23.07.2009 року № 843 «Про внесення змін до Порядку справляння збору та використання коштів на розвиток виноградарства, садівництва і хмелярства». URL: http://zakon4.rada.gov.ua/laws/show/843-2009-п (дата звернення: 15.11.2020)

8. Програма стимулювання економіки для подолання наслідків COVID-19. URL: https://www.kmu.gov.ua/ storage/app/sites/1/18\%20-\%20Department/18\%20 -\%20PDF/programa.pdf (дата звернення: 15.11.2020).

\section{REFERENCES:}

1. Reitynh Doing Business. [Rating Doing Business]. Available at:https://www.ukrinform.ua/rubric-eco- nomy/2805261-rejting-doing-business.html (accessed 15 November 2020).

2. Rylieiev S.V., Romanchuk A.L. (2013) Investytsiina pryvablyvist: vydy ta pidkhody do yii otsinky [Investment attractiveness: types and approaches to its evaluation]. Chernivtsi: Chernivetskyi torhovelno-ekonomichnyi instytut KNTEU.

3. Petrychko M.M. (2014) Metodychni pidkhody do otsinky efektyvnosti funktsionuvannia systemy investytsiinoho zabezpechennia innovatsiinykh protsesiv $u$ vynohradarsko-vynorobnii haluzi Ukrainy [Methodical approaches to the assessment of the effectiveness of the system of investment support of innovation processes in the viticulture and winemaking industry of Ukraine]. Kherson: Naukovyi visnyk Khersonskoho derzhavnoho universytetu.

4. Derzhavna sluzhba statystyky Ukrainy. [State Statistics Service of Ukraine]. Available at: http://www.ukrstat.gov.ua (accessed 15 November 2020).

5. Kravchuk A.O. (2019) Problemy ta priorytetni napriamky rozvytku vynohradarsko-vynorobnii haluzi Ukrainy: monohrafiia [Problems and priority directions of development of viticulture and wine industry of Ukraine: monograph.]. Ekonomika ta pidpryiemnytstvo, p. 41.

6. Derzhavna fiksalna sluzhba Ukrainy [State Fixed Service of Ukraine]. Available at: http://sfs.gov.ua (accessed 15 November 2020).

7. Postanova Kabinetu Ministriv Ukrainy vid 23.07.2009 roku № 843 "Pro vnesennia zmin do Poriadku spravliannia zboru ta vykorystannia koshtiv na rozvytok vynohradarstva, sadivnytstva i khmeliarstva". [Resolution of the Cabinet of Ministers of Ukraine of July 23, 2009 № 843 "On Amendments to the Procedure for Collection and Use of Funds for development of viticulture, horticulture and hop growing]. Available at: http://zakon4.rada.gov.ua/laws/show/843-2009-p (accessed 15 November 2020).

8. Prohrama stymuliuvannia ekonomiky dlia podolannia naslidkiv COVID-19. [Economic stimulus program to overcome the effects of COVID-19]. Available at: https://www.kmu.gov.ua/storage/app/sites/1/18\%20 -\%20Department/18\%20-\%20PDF/07.2020/programa (accessed 15 November 2020). 